С.О. Кірсанов

Центральний науково-дослідний інститут Збройних Сил Украӥни, Київ

\title{
МЕТОДИЧНИЙ ПІДХІД ДО ОБґРУНТУВАННЯ ВИМОГ ДО ОПЕРАТИВНОСТІ РОБОТИ ОРГАНІВ УПРАВЛІННЯ ПЕРСПЕКТИВНОЇ АВТОМАТИЗОВАНОЇ СИСТЕМИ УПРАВЛІННЯ ВІЙСЬКАМИ
}

\begin{abstract}
Статтю присвячено розробленню методичного підходу до обтрунтування вимог до оперативності роботи органів управління (ОУ) перспективної автоматизованої системи управління військами (АСУВ). Відомо, щзо одним із пріоритетних завдань оборонної реформи є створення на основі сучасних інформаційних технологій єдиної автоматизованої системи управління Збройними Силами України (САСУ ЗС України) як основи системи управління силами оборони держави. Але на теперішній час ї̈ стан є незадовільним унаслідок недосконалості існуючого методичного апарату з обтрунтування вимог до перспективних АСУВ, як ї̈ складових. У першу чергу це стосується вимог до оперативності роботи ОУ. Використання наявного методичного апарату дозволяє обгрунтувати за допомогою часткових показників функціонування ОУ орієнтовні (прогнозовані) значення показника ймовірності своєчасного виконання завдань ОУ протягом певного часу щуодо управління військами, який визначено основним показником оперативності роботи ОУ. При цьому не враховуються особливості та можливості ОУ щуодо виконання своєї головної роботи під час підготовки та застосування військ - роботи з інформаџією, яка иџиркулює на етапах ичиклу управління військами. Саме обсяги інформаџії, з якими необхідно службовим особам ОУ виконати певні дії (отримати, обробити, узагальнити, надіслати), визначають тривалість кожного етапу та циклу управління військами у цілому. Для досягнення мети статті ї̈ автором розроблено методичний підхід, який дозволяє обтрунтувати з позиції кібернетики та дослідження операцій послідовний порядок моделювання процесу автоматизованого управління у перспективній АСУВ типу C4ISR. Даний підхід є основою для розроблення у подальшому відповідного методу обтрунтування вимог до оперативності роботи ОУ, а також формулювання висновків $i$ рекомендацій щзодо досягнення ї̈ необхідного рівня.
\end{abstract}

Ключові слова: теорія управління, автоматизована система управління військами, об'єкт управління, математична модель, цикл управління військами, засоби автоматизованого управління, C4ISR.

\section{Вступ}

Постановка проблеми у загальному вигляді. Як відомо [1-2] для реалізації положень Воєнної доктрини України, Концепції розвитку сектора безпеки і оборони України Стратегічним оборонним бюлетенем України визначено цілі, основні завдання оборонної реформи та очікувані результати їх досягнення 3 урахуванням існуючих воєннополітичних загроз та викликів. При цьому одним із пріоритетних завдань оборонної реформи є створення на основі сучасних інформаційних технологій єдина автоматизована система управління Збройних Сил України (САСУ ЗС України) як основи системи управління силами оборони держави [3].

Завдання поступово реалізується шляхом упровадження у діяльність органів управління (ОУ) та військ (сил) комплексної автоматизації процесів оперативного (бойового) управління, розвідки та спостереження 3 урахуванням проектних рішень, стандартів країн - членів HATO C4ISR. Але, незважаючи на це, стан САСУ ЗС України не відповідає вимогам, які до неї висуваються [3]:
- автоматизовано окремі функції (процеси) органів управління ОУ (10-30\% від потреби), що практично не впливає на підвищення оперативності їх роботи;

- наявне спеціальне програмне забезпечення відповідає потребам пунктів управління лише на $12-$ $15 \%$, що не дозволяє командувачам якісно обгрунтовувати рішення;

- інформаційні ресурси 3С України не упорядковані, частково класифіковані, не поєднані у відповідне інформаційне середовище, що не забезпечує оперативне управління військами;

- складові САСУ ЗС України системи, засоби автоматизованого управління переважно технічно та інформаційно несумісні, що в майбутньому призведе до проблем з їхньою інтеграцією та забезпеченням оперативного та стійкого управління військами, тощо.

Такий стан САСУ ЗС України спричинений недосконалістю існуючого методичного апарату з обгрунтування вимог до перспективних автоматизованих систем управління військами (АСУВ), як іiі складових. У першу чергу це стосується вимог до 
оперативності роботи ОУ, які є визначальним елементом будь-якої системи управління, що обумовлює актуальність теми статті.

Аналіз останніх досліджень і публікацій. Аналіз останніх досліджень і публікацій стосовно наявного методичного апарату з обгрунтування вимог до оперативності роботи ОУ АСУВ, 3 огляду на іiі складність, розгалуженість та ієрархічність, показав, що його розробленню та розвитку приділяли недостатньо уваги. Як правило в основу методик покладені методи: системного аналізу [4], експертного оцінювання, аналогій [5-6], емпіричні методи, що застосовуються під час випробувань окремих програмно-технічних рішень АСУВ, які створюються у ЗС України [7]. Використання цих методів дозволяє обгрунтувати за допомогою часткових показників функціонування ОУ (укомплектованість, навченість службових осіб, їх злагодженість, можливі бойові втрати під час операції (бою)) орієнтовні (прогнозовані) значення показника ймовірності своєчасного виконання завдань ОУ протягом визначеного часу щодо управління військами. При цьому не враховуються особливості та можливості ОУ щодо виконання своєї головної роботи під час підготовки та застосування військ - роботи 3 інформацією, яка циркулює на етапах циклу управління військами. Саме обсяги інформації, з якими необхідно виконати певні дії (отримати, обробити, узагальнити, надіслати) службовим особам ОУ, визначають тривалість кожного етапу та циклу управління військами у цілому.

Метою статті $\epsilon$ розроблення методичного підходу до обгрунтування вимог до оперативності роботи органів управління перспективної АСУВ.

\section{Виклад основного матеріалу}

Змістовний аналіз терміна “оперативність” як вимоги до: процесу управління військами, роботи ОУ, СУ військами, представлений у табл. 1, показав, що визначальним елементом будь-якої системи управління є ОУ [8-10].

Саме від своєчасності та якості його роботи, у першу чергу, залежить своєчасне отримання, здійснення аналізу (оброблення, узагальнення) вхідної інформації з оперативно-тактичної обстановки, прийняття, виходячи 3 цього, ефективного рішення, планування відповідних заходів, своєчасна постановка задач підлеглим і здійснення ефективного контролю за виконанням ними спланованих заходів, а також проведення інших дій, спрямованих на підвищення ефективності бойового застосування військ для досягнення мети операції (бою).

Тобто досягнення заданого рівня оперативності управління військами у перспективній АСУВ передбачає, в першу чергу, випередження противника у діях щодо планування, застосування військ та управління ними в операції (бою).

Таблиця 1

Зміст терміна “Оперативність”

\begin{tabular}{|c|c|c|}
\hline \multicolumn{3}{|c|}{ "Оперативність" } \\
\hline $\begin{array}{c}\text { до процесу } \\
\text { управління } \\
\text { військами }\end{array}$ & до роботи ОУ & $\begin{array}{c}\text { до СУ } \\
\text { військами }\end{array}$ \\
\hline $\begin{array}{l}\text { Оперативність } \\
\text { управління - це } \\
\text { здатність коман- } \\
\text { дувачів (коман- } \\
\text { дирів) і ОУ здій- } \\
\text { снювати управ- } \\
\text { ління військами } \\
\text { у терміни, які } \\
\text { забезпечують } \\
\text { успішне вико- } \\
\text { нання поставле- } \\
\text { них завдань, } \\
\text { тобто у стислі } \\
\text { терміни, що до- } \\
\text { зволяє випере- } \\
\text { дити противника } \\
\text { у діях, швидко } \\
\text { реагувати н на } \\
\text { зміни обстанов- } \\
\text { ки та своєчасно і } \\
\text { ефективно впли- } \\
\text { вати на війська в } \\
\text { інтересах досяг- } \\
\text { нення мети опе- } \\
\text { рації (бою). }\end{array}$ & $\begin{array}{l}\text { Оперативність } \\
\text { полягає у своє- } \\
\text { часному реагу- } \\
\text { ванні оу на } \\
\text { зміни обстанов- } \\
\text { ки, обміні між } \\
\text { взаємдіючими } \\
\text { ОУ інформацією } \\
\text { про стан, поло- } \\
\text { ження підпоряд- } \\
\text { кованих військ, } \\
\text { можливий хара- } \\
\text { ктер дій против- } \\
\text { ника та інші } \\
\text { зміни обстанов- } \\
\text { ки, доведенні } \\
\text { уточнених за- } \\
\text { вдань військам, } \\
\text { здійсненні по- } \\
\text { стійного опера- } \\
\text { тивного впливу } \\
\text { на хід ї вико- } \\
\text { нання та вмілого } \\
\text { розподілу } \\
\text { обов’язків між } \\
\text { офіцерами і зо- } \\
\text { середженні зу- } \\
\text { силь на вирі- } \\
\text { шенні головних } \\
\text { та першочерго- } \\
\text { вих завдань. }\end{array}$ & \begin{tabular}{lr}
\multicolumn{2}{l}{ Оперативність } \\
повинна & відпо- \\
відати & вимо- \\
гам, які & вису- \\
ваються & до \\
управління \\
військами.
\end{tabular} \\
\hline
\end{tabular}

Джерело: розроблено автором за даними [8-10].

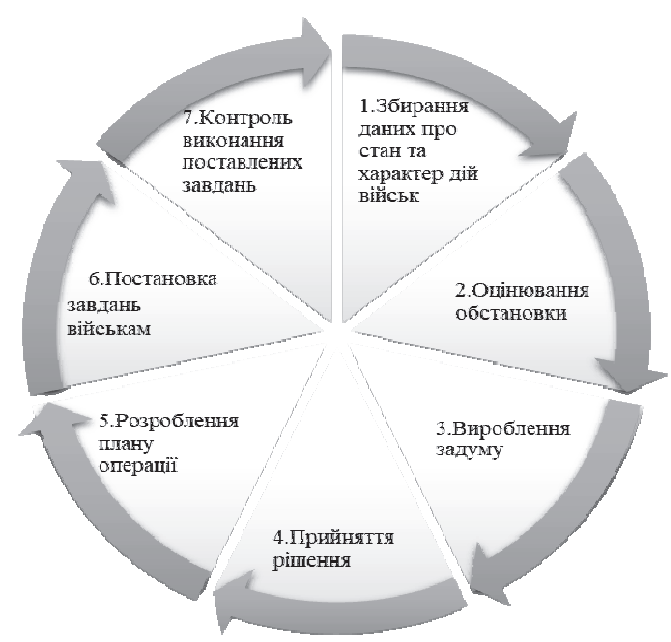

Рис. 1. Етапи циклу управління військами у ЗС України

Джерело: розроблено автором за даними [11]. 
Відповідно, саме тривалість дій ОУ щодо виконання покладених завдань 3 управління військами за визначеними у [11] етапами циклу управління (рис. 1), у першу чергу, визначає таку важливу властивість перспективної АСУВ, як іiї оперативність.

Зрозуміло, що оперативність управління військами безпосередньо визначається показником часу здійснення циклу управління.

На підставі зазначеного під оперативністю роботи ОУ щодо управління військами у перспективній АСУВ доцільно розуміти швидкість їх реакції (дій) на зміни обстановки, що склалася, з метою випередження противника у діях для досягнення мети операції (бою).

Методичний підхід розроблено з урахуванням структурно-логічної схеми обгрунтування вимог до АСУВ (рис. 2), яку було розглянуто у [12].

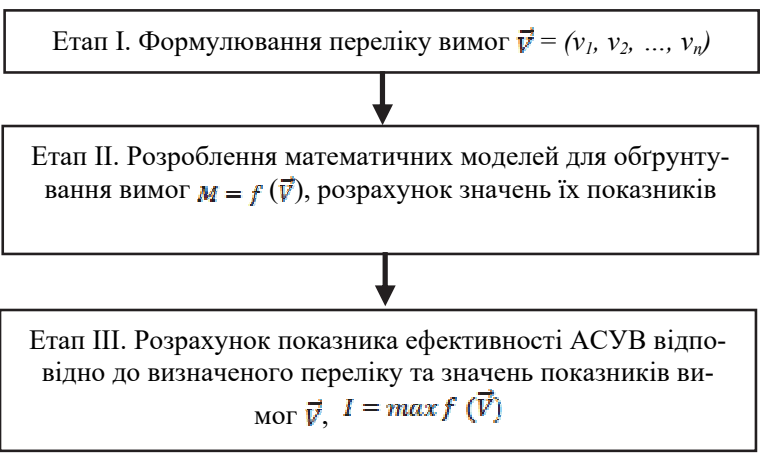

Рис. 2. Структурно-логічна схема обгрунтування вимог до АСУВ Джерело: розроблено автором.

Схема побудована відповідно до основних положень теорії управління та послідовністю своїх етапів передбачає під обгрунтуванням вимог до АСУВ розуміти визначення на підставі системного аналізу [13] переліку вимог, що обумовлюють ефективність системи, розроблення відповідних математичних моделей для розрахунку показників вимог та оцінки ефективності АСУВ.

Беручи до уваги викладені положення на рис. 3 представлено структурно-логічну схему методичного підходу до обгрунтування вимог до оперативності роботи органів управління перспективної АСУВ, який складається із 7 послідовних етапів.

Представлена на рис. 3 структурно-логічна схема методичного підходу є безпосередньо ії подальшим розвитком у напрямі обгрунтування вимог до оперативності роботи ОУ перспективної АСУВ.

Відповідно до схеми на першому етапі розробленого методичного підходу, з урахуванням змісту процесу управління військами, його мети та переліку основних завдань, виконанням яких досягається мета управління, уточнюються етапи циклу управління військами. При цьому переглядається перелік заходів, які містяться у кожному 3 них, їх послідовність та взаємозв'язок у процесі управління військами.
Результатом проведеної роботи є представлення циклу управління військами у формалізованому вигляді (у вигляді структурно-логічної схеми) з відповідним описом змісту та послідовності його етапів.

Етап I. Уточнення циклу управління військами за етапами та його формалізований опис

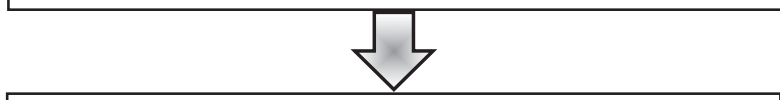

Етап II. Розроблення функціональної моделі процесу управління військами

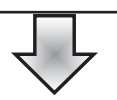

Етап III. Розроблення математичної моделі процесу управління військами

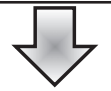

Етап V. Вибір математичної моделі для моделювання процесу управління військами в ACУВ типу C4ISR

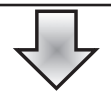

Етап VI. Математичний опис методу обгрунтування вимог до оперативності роботи ОУ перспективної АСУВ на основі вибраної математичної моделі процесу управління військами в ACУВ типу C4ISR

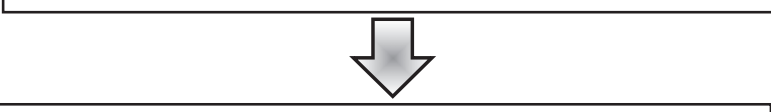

Етап IV. Обгрунтування порядку реалізації процесу управління військами у перспективній ACУB типу C4ISR. Розроблення організаційної та функціональної структури перспективної АСУB

Етап VІІ. Розроблення висновків та рекоменда-
цій щодо досягнення необхідного рівня опера-
тивності ОУ перспективної АСУВ

Рис. 3. Структурно-логічна схема методичного підходу до обгрунтування вимог до оперативності роботи ОУ перспективної АСУВ Джерело: розроблено автором.

Для забезпечення точного математичного опису процесу управління військами на другому етапі запропонованого методичного підходу 3 використанням основних положень теорії управління [1416] розробляється функціональна модель процесу управління військами. Ця модель у загальному вигляді відображає управління військами як динамічний безперервний нестаціонарний процес зі зворотним зв'язком, у якому ОУ виробляе (на підставі 
проведеного аналізу отриманих даних) рішення $\vec{u} \mathrm{i}$ доводить його до військ, які є об’єктом управління (ОбУ). При цьому від ОбУ до ОУ надходить інформація $\vec{x}$ щодо стану ОбУ після виконання (або під час виконання) рішення ОУ. У процесі управління повинно бути забезпечено своєчасний перехід військ, як ОбУ, зі стану, який склався на даний момент, до необхідного.

Унаслідок динамічного характеру процесу управління військами під управляючим впливом ОУ стан ОбУ постійно змінюється у часі, тобто

$$
\vec{x}(t)=f(\vec{x}(t), \vec{u}(t)),
$$

де $\vec{x}(t)$ - вектор стану ОбУ;

$\vec{u}(t)$ - вектор управління (рішення на операцію) ОУ, що характеризує нестаціонарність даного процесу.

На підставі цього управління військами може бути представлено як процес, який відбувається у часі та відображається як рух елемента по траєкторії у просторі станів $R^{n}$ (фазовому просторі) безперервної скінченномірної системи. Елемент простору станів є вектором стану даної системи і однозначно характеризує ii стан певним набором показників у будь-який момент часу.

На третьому етапі методичного підходу, з урахуванням попередніх напрацювань, розробляється математична модель процесу управління військами, яка відображає у векторній формі взаємозв'язок основних показників, що визначають протікання процесу управління військами у часі.

Ця модель дозволяє у векторному вигляді розглянути вплив кожного з етапів циклу управління на досягнення мети управління.

Четвертий етап методичного підходу передбачає обгрунтування порядку реалізації процесу управління військами у перспективній АСУВ типу S4ISR $[1 ; 3 ; 17]$.

На цьому етапі розглядаються особливості побудови та функціонування АСУВ типу S4ISR 3 точки зору кібернетики, а саме щодо:

- забезпечення цілеспрямованості (чіткого здійснення визначеної мети) управління;

- використання причинно-наслідкових та зворотних зв'язків між елементами АСУВ (засобами автоматизованого управління (ЗАУ), їх комплексами (КЗАУ));

- урахування впливу на елементи АСУВ зовнішнього середовища (дій противника, фізикогеографічних умов району операції), який призводить до стохастичності процесу управління військами;

- наявності обміну інформацією між елементами АСУВ як обов'язкової умови іії функціонування та збереження цілісності;

- динамічного характеру процесу управління, який здійснюється в АСУВ (постійної зміни стану у часі відповідно до інтенсивності потоку інформації, який виходить на кожному етапі циклу управління військами).

Відповідно до цього розробляється організаційна та функціональна структури перспективної АСУВ для реалізації автоматизованого управління військами, які, у першу чергу, повинні відображати порядок обміну інформацією різного виду у системі (командна, інформація про стан ОбУ) та механізм автоматизованих дій $з$ нею (отримання, оброблення, узагальнення, передавання) під час управління військами.

Ці структури повинні дозволяти за наявності необхідного спеціального математичного та програмного забезпечення з елементами штучного інтелекту за рішенням ОУ здійснювати управління військами у квазіавтоматичному режимі. Що, згідно 3 [1; 3; 18-20], відповідає класу АСУВ (за термінологією НАТО) C4, яка дає можливість повністю автоматизувати процеси збирання, оброблення та доведення інформації, забезпечує інформаційну та аналітичну підтримку прийняття рішення на основі моделювання результатів бойових дій.

На п’ятому етапі методичного підходу до обгрунтування вимог до оперативності роботи ОУ здійснюється вибір математичної моделі для моделювання процесу управління військами в АСУВ типу C4ISR. В основу вибору моделі має бути покладено те, що під час управління військами службові особи ОУ здійснюють передбачені етапами циклу управління операції винятково з інформацією. Час на виконання кожного етапу, а точніше - на виконання заходів, що його складають, визначає іiі обсяг. При цьому необхідно мати на увазі, що всі завдання щодо управління військами вирішуються у циклі управління безперервно і за досвідом навчань систематично через брак інформації на різних його етапах виникає необхідність повертатися до раніше вирішених завдань та періодично переглядати їх рішення $з$ подальшим уточненням для своєчасного досягнення мети операції.

Таким чином, під час функціонування перспективної АСУВ у ній безперервно здійснюється у часі процес перетворення отриманої інформації про стан ОбУ та обстановку, яка склалася, у командну інформацію шляхом підготовки прогнозів поведінки ОбУ залежно від різних варіантів замислу операції, вибору із цих варіантів одного, розроблення на його основі плану дій ОбУ в операції, здійснення управління ним, його впровадження та контроль за виконанням. Тобто відбувається рух інформації по колу за етапами циклу управління військами АСУВ. При цьому, зважаючи на стохастичність процесу управління, такі переходи інформації з одного етапу в інший відбуваються не у фіксовані, а у випадкові 
моменти часу, які заздалегідь передбачити неможливо.

Шостий та сьомий етапи методичного підходу, відповідно, мають на меті безпосередній математичний опис методу обгрунтування вимог до оперативності роботи ОУ перспективної АСУВ на основі вибраної математичної моделі процесу управління військами в ACУB типу C4ISR та розроблення висновків і рекомендацій щодо досягнення необхідного рівня оперативності ОУ перспективної АСУВ.

Необхідно зазначити, що, враховуючи особливості побудови та функціонування АСУВ, розроблені висновки та рекомендації повинні, по-перше, бути спрямовані на практичне покращення автоматизованого управління військами у перспективній АСУВ, по-друге - стосуватися не тільки службових осіб ОУ відповідного рівня, а й засобів автоматизованого управління (їх комплексів), що забезпечують процес автоматизованого управління військами.

\section{Висновки}

Таким чином, у статті розроблено методичний підхід до обгрунтування вимог до оперативності роботи органів управління перспективної АСУВ. Він визначає $з$ позиції кібернетики та дослідження операцій послідовний порядок моделювання процесу автоматизованого управління у перспективній ACУB типу C4ISR. Перспективами подальших досліджень $є$ розроблення відповідного методу обгрунтування вимог до оперативності роботи ОУ, а також формулювання висновків і рекомендацій щодо досягнення їі необхідного рівня.

\section{Список літератури}

1. Про рішення Ради національної безпеки і оборони України від 20.05.2016 “Про Стратегічний оборонний бюлетень України” : Указ Президента України від 06 черв. 2016 р. № 240/2016. Київ : АПУ, 2016. 61 с.

2. Про рішення Ради національної безпеки і оборони України від 13.09.2017 “Про Концепцію реформування та подальшого розвитку системи управління державою в умовах надзвичайного стану і в особливий період” : Указ Президента України від 25 верес. 2017 р. № 283/2017. URL: https://zakon.rada.gov.ua/laws/show/283/2017\#Tехt (дата звернення 05.04.21).

3. Концепція відомчих програм створення Єдиної автоматизованої системи управління Збройних Сил України, єдиної інформаційної системи управління оборонними ресурсами та інформаційної інфраструктури до 2020 року : затв. Мін. оборони України від 12 трав. 2018 р. Київ : МОУ, 2018. 13 с.

4. Кірсанов С. О., Азаревич В. О., Манько О. О. Один із поглядів на зміст та послідовність проведення досліджень щодо обгрунтування оперативно-тактичних вимог до складової єдиної автоматизованої системи управління Збройних Сил України. Збірник наукових праџь Центрального науково-дослідного інституту ЗС України. 2011. № 3(57). C. 221-236.

5. Шуєнкін В. О. До питання оцінювання ефективності системи управління військами (силами). Наука і оборона. 2010. № 4. C. 23-28.

6. Кірсанов С. О., Островський С. М. Методичний підхід до оцінювання рівня автоматизації роботи органів управління. Сучасні інформачійні технології у сфері безпеки та оборони. 2018. № 3(33). С. 77-80.

7. Ткачук П. П., Бударецький Ю. І., Щавінський Ю. В., Прокопенко В. В. Вплив засобів автоматизації управління підрозділами і вогнем артилерії на ефективність іï застосування. Військово-технічний збірник. 2015. № 12 . С. $75-82$.

8. Основы теории управления войсками / под ред. П. К. Алтухова. Москва : Воениздат, 1984. 221 с.

9. Управління військами (силами) в операції (бою). Ч. І. Основи управління військами (силами) : підр. Київ : HAOУ, 2010. $208 \mathrm{c}$.

10. Иванов Д. А., Савельев В. П., Шеманский П. В. Основы управления войсками в бою. Москва : Военное изд. МО СССР, 1977. $389 \mathrm{c}$.

11. Гусак Ю. А., Кірсанов С. О., Островський С. М. Математична модель процесу управління військами у просторі станів. Збірник наукових прачь Центрального науково-дослідного інституту ЗС України. 2021. № 1(96). С. 18-30.

12. Гусак Ю. А., Кірсанов С. О., Власюк В. М. Аналіз існуючого методичного апарату з обгрунтування вимог до автоматизованої системи управління військами. Збірник наукових праџь Центрального науково-дослідного інституту ЗС України. 2020. № 4(95). С. 14-24.

13. Тараканов К. В., Овчаров Л. А., Тарышкин А. Н. Аналитические методы исследования систем. Москва : Сов. радио, 1974. $240 \mathrm{c}$.

14. Понтрягин Л. С., Болтянский В. Г., Гамкрелидзе Р. В., Мищенко Е. Ф. Математическая теория оптимальных процессов. Москва : Изд. физико-математической литературы, 1961. 391 с.

15. Ли Э. Б., Маркус Л. Основы теории оптимального управления. Москва : Наука, 1972. 576 с.

16. Оптимальное управление / под редакцией Ю. И. Топчеева. Москва : Машиностроение, 1968. 764 с.

17. Гусак Ю. А., Кірсанов С. О., Островський С. М. Математична модель автоматизованого управління військами в AСУВ типу C4ISR. Modern Information Technologies in the Sphere of Security and Defence. 2021. № 1(40). C. 4754.

18. Сидорин А. Н., Прищепов В. М., Акуленко В. П. Вооружённые силы США в XXI веке: военно-теоретический труд. Москва : Кучково поле, 2013. 800 с.

19. Макаренко С. И., Иванов М. С. Сетецентрическая война - принципы, технологии, примеры и перспективы: монография. Санкт-Петербург : Наукоёмкие технологии, 2018. 898 с. 
20. Паршин С., Кожанов Ю. Концепции сетецентрического боевого управления ВС США, Великобритании и ОВС НАТО. Общее и различия. Зарубежное военное обозрение. 2010. № 4. С. 7-18.

\section{Відомості про автора:}

\section{Кірсанов Сергій Олександрович}

кандидат технічних наук старший науковий співробітник докторант Центрального науково-дослідного інституту Збройних Сил України,

Київ, Україна

https://orcid.org/0000-0002-9696-0369

\section{Information about the author:}

\section{Serhii Kirsanov}

Candidate of Technical Sciences Senior Research

Doctoral Student of Central Research Institute

of the Armed Forces of Ukraine,

Kyiv, Ukraine

https://orcid.org/0000-0002-9696-0369

\title{
МЕТОДИЧЕСКИЙ ПОДХОД К ОБОСНОВАНИЮ ТРЕБОВАНИЙ ПО ОПЕРАТИВНОСТИ РАБОТЫ ОРГАНОВ УПРАВЛЕНИЯ ПЕРСПЕКТИВНОЙ АВТОМАТИЗИРОВАННОЙ СИСТЕМЫ УПРАВЛЕНИЯ ВОЙСКАМИ
}

\author{
С.А. Кирсанов
}

В статье разработан методический подход к обоснованию требований по оперативности работы органов управления (ОУ) перспективной автоматизированной системы управления войсками (АСУВ). Известно, что одной из приоритетных задач оборонной реформы является создание на основе современных информационных технологий единой автоматизированной системы управления Вооружёнными Силами Украины (ЕАСУ ВС Украины) как основы системы управления силами обороны государства. Однако на данное время её состояние является неудовлетворительным вследствие несовершенства существующего методического аппарата по обоснованию требований к перспективным АСУВ, как её составляющии. В первую очередь это касается требований по оперативности работы ОУ. Использование методического аппарата, имеющегося в наличии, позволяет обосновать при помощи отдельных показателей функционирования ОУ ориентировочные (прогнозируемые) значения показателя вероятности своевременного выполнения задач ОУ на протяжении какого-то времени по управлению войсками, который определен как основной показатель оперативности работы ОУ. При этом не учитываются особенности и возможности ОУ по выполнению своей главной работы во время подготовки и применения войск - работы с информацией, которая ииркулирует на этапах иикла управления войсками. Именно объёмы информации, с которыми необходимо служебным лицам ОУ выполнять определённые действия (получать, обрабатывать, обобщать, отправлять), определяют длительность каждого этапа и иикла управления войсками в целом. Для достижения иели статьи её автором разработан методический подход, который определяет с позиции кибернетики и исследования операций последовательный порядок моделирования процесса автоматизированного управления в перспективной ACУB mипа C4ISR. Данный поход является основой для разработки в дальнейтем соответствуюшего метода обоснования требований к оперативности работь ОУ, а также формулирования выводов и рекомендаций по достижению её необходимого уровня.

Ключевые слова: теория управления, автоматизированная система управления войсками, объект управления, математическая модель, иикл управления войсками, средства автоматизированного управления, C4ISR.

\section{METHODOLOGY OF REQUIREMENTS' JUSTIFICATION FOR EFFICIENCY OF COMMAND\&CONTROL OPERATIONS OF FUTURE AUTOMATED MISSION COMMAND SYSTEM}

\section{S. Kirsanov}

The article is devoted to highlighting the essence methodology of requirements' justification for efficiency of Command \& Control (C2) operations of future automated Mission command system (C4ISR). It is known that one of the priorities of defense reform is the development C4ISR of the Armed Forces of Ukraine based on a modern information technology as the foundation of the state defense forces C2. But at present its condition is unsatisfactory due to the lack of the existing methodological apparatus to justify the requirements for future C4ISR as its components. First of all, this applies to the requirements for the efficiency of the C2, which are the defining (main, most important) element of any $C 2$ system. The use of the existing methodological apparatus allows to substantiate with the help of inter-mediate indicators of the C2 approximate (predicted) values of the probability of timely performance of $C 2$ tasks for a certain period of time for Mission command, which is determined by the main indicator of C2 efficiency. This does not take into account the features and capabilities of the $C 2$ to perform its main function during the training and employment of force - information management that circulates at the stages of the Mission command's Battle Rhythm. It is the amount of information with which the C2 military authority must conduct certain actions (receive, process, summarize, send), determine the duration of each stage and the Mission command's Battle Rhythm as a whole. To achieve the goal of the article, its author proposed a methodology, which determines from the point of view of cybernetics and operations research the sequential order of modeling the process of automated Mission command in a future C4ISR interoperable with the NATO standards. This approach is the foundation for further development of an appropriate method of substantiation of the requirements for the efficiency of the C2, as well as the formulation of conclusions and recommendations for achieving its required level.

Keywords: command \& control, value of information, automated Mission command, Mission command's Battle Rhythm, C4ISR, methodology apparatus, efficiency of operation. 